The presentation draw some attention of radio and television, this also because in our Message to Parliament we had given some concrete examples of possible consequences of predictive medicine.

\section{Some conclusions}

Looking back at the project Predictive Medicine from the perspective of the Rathenau $\mathbf{h}$ stitute as a parliamentary TA institute, the following conclusions can be drawn:

- A project that takes a different course than is planned, is not because of that a failure; on the contrary it proved that predictive medicine was a subject which raised a lot of new and other questions than the Rathenau Institute expected;

- We had a big advisory group in which all possible antagonisms were built in: that proved to be not a workable construction;

- Conflicts should not be sought, but it is also not useful to avoid them at all costs; perhaps the discussion around predictive medicine is the forerunner of a coming paradigm discussion in and around medicine;

- There is a great difference in culture between many medical and genetical specialists and philosophers and sociologists, but also politicians.

\section{References}

de Vries, G. H.; Horstman, K.; Haveman, O., 1997 : Politiek van preventie. Normatieve aspecten van voorspellende geneeskunde. The Hague: Rathenau Instituut. Working Document 58

Horstman, K.; de Vries, G. H.; Haveman, O., 1999: Gezondheidspolitiek in een risicocultuur. Burgerschap in het tijdperk van de voorspellende geneeskunde. The Hague: Rathenau Institute. Study 38, p. 141-142

Kruijff, A. F.; Schreuder, R. F., 1999: Toekomstscenario's voorspellende geneeskunde. The Hague: Rathenau Institute. Working Document 73 Rathenau Institute, 2000: Goede tijding, slechte tijding (Good message, bad message). Bericht aan het Parlement. The Hague

Science 2001 Feb. 16;291(5507):1304-1351.

\section{Contact}

Koos van der Bruggen

Rathenau Institute

P.O. Box 85525, NL-2508 CE The Hague

Tel.: + 31 (0) 703421542

Fax: + 31 (0) 703633488

e-mail: K.vanderBruggen@Rathenau.knaw.nl

Homepage: http://www.rathenau.knaw.nl

\section{POST study on Pharmaco- genetics}

\author{
by David Cope and Peter Border, Parliamen- \\ tary Office of Science and Technology
}

Genetics is an important factor in the overall impact of a person's reaction to a specific drug. With increasing knowledge about the human genome, pharmacogenetic testing will become more important, as it opens up the prospect of personalised medicine, where each patient receives the treatment most appropriate to him. It poses however also challenges to regulators and raises questions about the nature of the information derived by phamacogenetic profiling.

\section{What is pharmacogenetics?}

It has long been known that different people may react differently to the same drug. Indeed, a rule of thumb has evolved in the pharmaceutical industry, that only around one in three people given a particular drug will benefit from it. The remaining two thirds either will not respond to the drug at all, or may suffer an adverse reaction.

Pharmacogenetics is an attempt to explain this variation in the way individuals respond to drugs in terms of genetics. This is not to suggest that genetics is the only factor involved. An individual's response to a drug will also be influenced by a range of other (environmental) factors such as what and when they last ate. Other factors such as compliance with a drug regime (the extent to which an individual takes the right drug at the right time) will also contribute to the overall impact of the drug. But it 
has become increasingly apparent in recent years that genetics is also an important factor and the more that is known about the human genome, the more important pharmacogenetics may become.

\section{Drug responses and genetic variation}

While we all share the same genome, we each have our own unique version of it. For instance, coinciding with the February 2001 publication (Nature) of the first draft of the human genome, the International SNP Map Working Group issued a map documenting 1.42 million sites of known individual variations within the genome (SNPs are single nucleotide polymorphisms - sites at which single base differences occur).

Some of these genetic variations will $\mathfrak{c}$ cur in the genes that code for proteins that interact with drugs. Such variations may be important for two main reasons. First, proteins may themselves be drug targets. Because proteins perform many essential tasks within the body (messengers, carriers, receptors, etc.), drugs are often designed to bind a specific protein in order to exert their therapeutic effect. Variations in these target proteins may thus affect the way an individual responds to a drug. Researchers may increasingly be able to apply knowledge of variations in target proteins to drug design.

Second, proteins are also responsible for breaking down drugs in the body (Wolf et al. 2000).In particular, one family of proteins - the so-called cytochrome P450s - does this for most of the drugs used in modern medicine today. As discussed in more detail below, variations in these proteins can affect the rate at which a drug is broken down and the nature of the breakdown products. Such variations have been the focus of much recent attention because they can affect:

- Drug efficacy. For instance, some individuals have multiple copies of a gene (cyp2d6) that codes for a protein that (inter alia) breaks down tricyclic antidepressants such as nortriptyline. Such individuals break the drug down at such a high rate that it is virtually impossible for the drug to achieve a therapeutic dose.
- $\quad$ Dose required. The rate at which a drug is broken down affects the dose required to achieve a therapeutic effect. For instance, some individuals have inactivating mutations in a gene (cyp2c9) coding for another member of the cytochrome P450 family that is normally involved in breaking down drugs such as warfarin (an anticoagulant). Such individuals thus need only very low doses of the drug.

- Adverse reactions and toxicity. Variations in genes coding for the cytochrome P450 family of proteins also affect the metabolic route by which drugs are broken down. Some individuals may thus break down drugs into harmful metabolites that can cause adverse reactions, whereas others will not.

- Drug activation. Some drugs are given as inactive pro-drugs, relying on enzyme action to convert them to the active form. One such example is codeine, which is converted to its active form (morphine) by cyp2d6; people with inactivating mutations in this gene derive no therapeutic benefit from the drug.

\section{Pharmacogenetic testing to predict drug responses}

Researchers are currently aware of at least 30 genes coding for proteins involved in drug metabolism. As discussed previously, variations in these gene sequences can lead to considerable differences in the rate and manner in which people break down drugs. The expectation is that more such variations will be mapped and characterised in the near future. As knowledge of which genetic variations are linked to which drug responses improves, then doctors may increasingly be able to devise (pharmacogenetic) tests to predict how a particular patient will respond to a particular type of drug. Many within the pharmaceutical industry see such developments as having great potential for personalising medicine, where the "right drug" is matched with the "right patient". If they are right, then pharmacogenetics will raise a number of issues that policy makers will need to consider. These are discussed in more detail below. It is worth pointing out, however, that some are more sceptical about 
the potential for pharmacogenetics, arguing that it is by no means clear what proportion of individual variation is accounted for by genetics.

\section{Implications for policy makers}

\section{Ethical considerations concerning pharmaco- genetic testing}

Ethical issues concerning genetic tests have been the subject of much debate in recent years. To date this has been concerned with genetic tests for genes involved with disease. These have largely been tests for relatively rare single gene disorders such as cystic fibrosis, but may increasingly include tests for genes implicated in common complex disorders such as cancer, diabetes, etc. (see Fig. 1). Issues raised by "disease genetic testing" and considered by regulatory bodies throughout Europe include:

- informed consent (e.g. the need to provide counselling before and after a test);

- whether or not tests should be conducted if no appropriate treatment is available;

- test validation (particularly for predictive tests for common complex disorders);

- whether third parties such as employers or insurers should have access to genetic information;

- $\quad$ and, if so, under what circumstances.

Fig. 1: Pharmacogenetics and other types of genetic testing

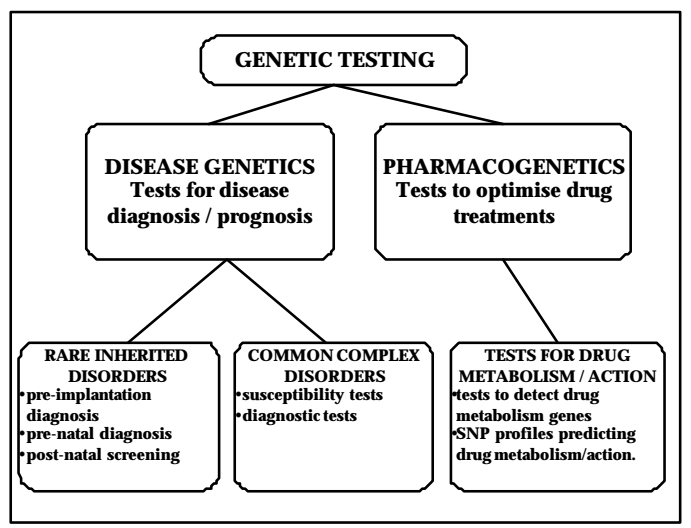

To what extent do similar considerations apply to pharmacogenetic tests? Some have argued that all genetic tests raise similar issues by virtue of the fact that they reveal genetic information about the person taking the test. Others, including many in the pharmaceutical industry, feel that it is the nature of the information that is important, not the nature of the test by which it was derived (Roses 2000). They see a clear distinction between information relating to genetic disease and information concerning likely response to a drug (see Fig. 1). The former may be used to the patient's medical advantage but may also be of interest to third parties such as insurers and employers, who might seek to use it in a way that discriminates against the patient. They argue that pharmacogenetic data can only be used to the patient's medical benefit; it is of no interest to third parties and is thus unlikely to be used in a discriminatory way. This may mean that some of the ethical considerations that apply to disease genetics may be avoided by pharmacogenetics.

Not all agree with this view. Some have suggested that a person's pharmacogenetic profile may itself be of interest to third parties, for example, if it showed that the individual was particularly difficult to "match up" to currently available treatments. Others have questioned the distinction between disease genetics and pharmacogenetics, pointing out that it depends on the assumption that the latter will yield information only on likely responses to drugs. Suppose it subsequently turned out that the same variations that affect drug metabolism (and thus predict drug responses) could also be used to deduce something about an individual's future susceptibility to genetic disease. Under these circumstances, the information might be of interest to third parties and consideration may have to be given to issues such as counselling, confidentiality, etc. It must be stressed that there is no evidence to suggest that this will be the case; it is more a matter of speculating that it is not entirely implausible that genetic variations in metabolic enzymes might have more far-reaching biological consequences. One issue for policy makers here is to consider mechanisms by which the "usefulness" of the information yielded by pharmacogenetic tests can be monitored. 


\section{Clinical trials and adverse drug reactions}

The key feature of pharmacogenetics is that it allows drugs to be targeted at sub-groups of the population whose genetic profile predicts that they will respond to them best. Indeed many pharmaceutical companies have already started collecting genetic information in the early stages of clinical trials. By the time a new drug is ready to be tested in thousands of patients in Phase III trials, researchers may already have a pretty good idea of which patients are likely to benefit most from it. If the drug can be tested on patients with the appropriate genetic profile in the final phase clinical trial, then fewer patients may be needed to establish efficacy. This is good news for pharmaceutical companies since it raises the prospect of smaller, faster and cheaper clinical trials.

One concern about clinical trials in general is that they may miss very rare adverse drug reactions that become apparent only after the drug has been given to tens of thousands of patients. Current trials may already involve too few patients to detect some such adverse reactions; any reduction in the number of patients involved in clinical trials (e.g. because of pharmacogenetic profiling) might therefore further reduce the likelihood of detection. However, pharmacogenetics also offers the potential for improved surveillance for adverse drug reactions. Keeping blood samples from all patients receiving a new drug in the first few years it is on the market would allow pharmacogenetic profiling of any adverse reactions detected in this larger group of people. Information linking specific genetic variations with very rare adverse reactions to a drug could thus be "fed back" into the marketing approval. In this way, the pharmacogenetic profile of the sub-group of patients for which the drug was approved could be continually "fine tuned".

\section{Overview}

Pharmacogenetics is just one part of a much wider trend that is putting genetics at the heart of modern medicine. Notwithstanding recent suggestions that we possess fewer genes than anticipated, the coming years will see great advances in our understanding of the role our genes play in many common diseases. All of this points towards a bigger emphasis on genebased tests, whether for pharmacogenetic, dagnostic or other purposes.

Healthcare providers such as the UK's National Health Service (NHS) will thus have to consider the potential financial and organisational issues raised by such trends. For instance, NHS genetic testing in the UK has evolved to meet the needs of patients suffering from relatively rare genetic disorders: it is currently centred on 50 or so regional laboratories. Basing drug prescriptions on pharmacogenetic profiles or involving other types of genetic testing in diagnosis/classification of more common disorders implies a more accessible, local, organisation of services.

It also implies that doctors, nurses, and medical technicians will require more know ledge of recent developments in clinical genetics than is currently the case. This can be addressed through changing curricula and by continued professional training, although such initiatives require time and money to set up and to take effect. Greater numbers of genetic counsellors may also be needed for some types of genetic tests (although as discussed above not necessarily for pharmacogenetic profiling), and consideration may need to be given to novel ways of delivering counselling.

Overall then, pharmacogenetics creates both opportunities and challenges for policy makers. It opens up the prospect of personalised medicine, with each patient receiving the treatment most appropriate to them. It also promises to speed up the clinical trials process and reduce the numbers of patients suffering adverse reactions to new drugs. However, this poses challenges for regulators and may also raise questions about the nature of the information derived by pharmacogenetic profiling. 


\section{References}

Nature, 409, 15 Feb 2001

Wolf $C$. R. et al., BMJ 320, 987-90, 2000

Roses, A. D., Lancet, 35, 1358-61, 2000

\section{Contact}

Peter Border

Parliamentary Office of Science and Technology (POST)

House of Commons

7, Milbank, UK-London SW1P 3JA

Tel.: + 441712192 840; Fax: + 441712192849

e-mail: BORDERP@parliament.uk

Homepage:

http://www.parliament.uk/post/home.htm

$\gg$

\section{Die systematische Evaluation medizinischer Interventionen am Beispiel Erythropoietin bei Tumoranämie}

\author{
von Claudia Wild, Institut für Technikfolgen- \\ Abschätzung, Wien
}

Die Diskussion um Rationierung vs. Rationalisierung von Leistungen im Gesundheitswesen ist vor allem für die Ausrichtung der Gesundheitspolitik von Bedeutung. Konkrete Evaluationen haben dabei zumeist medizinische Interventionen in der Grauzone zwischen Rationierung, d. h. dem Vorenthalten wirksamer Gesundheitsleistungen, und Rationalisierung, d. h. der Eliminierung eindeutig unwirksamer Interventionen, zum Inhalt. Als Exempel dient ein Assessment zu Erythropoietin bei Tumoranämien.

Die Ergebnisse der Behandlung Tumorinduzierter Anämien mit Erythropoietin sind teilweise unbefriedigend: Nur 50 - $60 \%$ anämischer Tumorpatienten sprechen auf EPO an. Gleichzeitig werden in Krankenanstalten und Sozialversicherungen für onkologische Indikationen zweistellige EPO-Verbrauchszuwächse verzeichnet. Ein Assessment legt nun die wissenschaftliche Basis für einen ,angemessenen“ Einsatz von Erythropoietin bei Tumoranämien:
Es macht Aussagen zu gesichertem und fraglichem Nutzen für Tumorpatienten.

Die Ergebnisse der Behandlung renaler Anämien mit r-HuEPO (gentechnologisch hergestelltes Erythropoietin) lösten - aufgrund der guten Ergebnisse mit 80 bis $95 \%$-iger Respondenz - die Erwartung aus, dass die Ergebnisse der Behandlung anderer chronischer Anämien mit Erythropoietin ähnlich erfolgreich wären. Während allerdings Anämien bei chronischen Nierenerkrankungen durch einen Mangel an Erythropoietin, d. h. monokausal, bedingt sind, sind die Ursachen für Anämien bei Krebserkrankungen vielfältiger Natur. Dementsprechend sprechen nur 50 bis $60 \%$ der Patienten mit chronischer Anämie bei Krebserkrankung auf r-HuEpo an.

Nachdem es sich bei r-HuEPO um ein sehr kostspieliges Präparat handelt, und in Österreich wie auch in den USA r-HuEPO nicht nur in einem weitaus breiteren Indikationsrahmen als in anderen westlichen Ländern zugelassen ist, sondern auch wesentlich häufiger angewendet wird, stellen die Kostenträger zunehmend den Bedarf nach Richtlinien zum Einsatz von EPO und zur Früherkennung jener 40 $50 \%$ der Patienten fest, die nicht auf die r-HuEPO Gabe ansprechen.

R-HuEPO wurde in Österreich in einer lokalen Registrierung - damals noch nicht EUMitglied - Anfang der 90er Jahre, als einem der ersten Länder weltweit, für Tumoranämien zugelassen. Entsprechend den Vorschriften für gentechnologisch hergestellte Pharmaprodukte ist eine zentrale Registrierung bei der 1994 ins Leben gerufenen EMEA (European Agency for the Evaluation of Medicinal Products) notwendig. Die EMEA schränkte bislang die weitgefasste Indikation der Tumoranämien auf Anämien bei platin-hältiger Chemotherapie ein, ließ aber im Juni 2000 EPO auch für den breiteren Indikationsbereich Chemotherapieinduzierter Anämie zu. Dieser Schritt ist durch die historische Entwicklung, nicht durch die klinischen Ergebnisse zu erklären.

\section{Anämieabklärung}

Erythropoietin, ein beim gesunden Erwachsenen vor allem in den Nieren gebildetes Hormon, greift an Vorläuferzellen der Erythrozyten im Knochenmark an und fördert so die 